\title{
Calcium Concentration in Ground Water of Punjab Satluj Floodplain (India): Spatio-temporal Analysis from 1970-2011
}

\author{
Harsimrat Kaur Gill
}

Ph.D scholar in Center of Advanced Study in Geography, Panjab University, Chandigarh-160014, India

\begin{abstract}
Maximum permissible limit of calcium ion concentration is $75 \mathrm{mg} / \mathrm{L}$. In study area, range of calcium concentration in groundwater was varied with time. Calcium concentration in groundwater exceeds permissible consumption limit with time as it ranged between 33 to $110 \mathrm{mg} / \mathrm{L}$ in 1970 and reached to $206 \mathrm{mg} / \mathrm{L}$ during 1980 with 69.42 and 76.74 mean respectively; in 1990, 2000 and 2011 calcium concentration existed between 14 to $140 \mathrm{mg} / \mathrm{L}, 17$ to $68 \mathrm{mg} / \mathrm{L}$ and 8 to $78 \mathrm{mg} / \mathrm{L}$ respectively. Concentration of calcium is effected by the nature of hydrogen ion concentration, carbon dioxide and carbonate minerals.
\end{abstract}

Keywords: Groundwater, Floodplain, Calcium, Contamination, Spline

\section{Introduction}

Spatial-temporal variation in concentration of calcium ion in groundwater of Punjab Satluj floodplain has been analyzed from 1970 to 2011. Punjab Satluj floodplain covered parts of Phillaur Block of Jalandhar District; Aur, Nawanshahr and Balachaur Block of Shahid Bhagat Singh Nagar District; Chamkaur Sahib Block of Rupnagar District and Machhiwara, Ludhiana II and Ludhiana I Block of Ludhiana District of State Punjab Country India. This part is stretched between $30^{\circ} 32^{\mathrm{ee}} \mathrm{N}$ to $31^{\circ} 35^{\mathrm{ec}} \mathrm{N}$ and $75^{\circ} 05^{\mathrm{ee}} \mathrm{E}$ to $76^{\circ} 44^{\mathrm{ee}} \mathrm{E}$ latitudes and longitudes respectively and covers 1042.75 square kilometers area of Indian Punjab.

Fifty wells have been selected for understanding the changing pattern of calcium concentration in groundwater of Punjab Satluj floodplain. Secondary data provided by Department of Soil and Conservation, Punjab and Central Groundwater Board, India has been used and spline interpolation technique has been applied to that analyzed, processed point data for displaying it in isolines form.

\section{Discussion and Analysis}

Maximum permissible limit of calcium ion concentration in water for consumption is $75 \mathrm{mg} / \mathrm{L}$ [1]. This value is affected by the $\mathrm{pH}$, carbon dioxide and carbonate minerals [2-3]. Excessive concentration of calcium in water increased the risk of cardiovascular diseases in humans [4] and also increased the hardness of water [5]. In study area, range of calcium concentration in groundwater was varied with time (table 1). For 1970, it ranged between 33 to $110 \mathrm{mg} / \mathrm{L}$ with 69.42 mean and 23.92 standard deviation (table 1). Areas characterized with beyond permissible calcium ions include western and southern Balachaur Block and eastern Nawanshahr Block of Shahid Bhagat Singh Nagar District. It also incorporates whole Chamkaur Sahib Block of Rupnagar District and eastern part of Ludhiana District. In the western part of study area, unfit groundwater was observed in north western part of Aur Block of Shahid Bhagat Singh Nagar District, central part of Phillaur Block of Jalandhar District and western part of Ludhiana District (figure 1 (a)). For 1980, calcium concentration in groundwater of study area was increased and reached at $206 \mathrm{mg} / \mathrm{L}$ for some areas. This high range i.e. 187.5 to $206 \mathrm{mg} / \mathrm{L}$ calcium contaminated groundwater was covered two distinctive areas, one was observed in north western Nawanshahr Block of Shahid Bhagat Singh Nagar District and other include a circular patch consisting south western part of Nawanshahr Block (Shahid Bhagat Singh Nagar District), south eastern part of Aur Block of Shahid Bhagat Singh Nagar District and north eastern Ludhiana II Block of Ludhiana District (figure 1 (b)).

Table 1: Calcium Concentration in Punjab Satluj Floodplain: Variability Analysis from 1970 to 2011

\begin{tabular}{|c|c|c|c|c|c|c|}
\hline & $\begin{array}{c}\text { Maximum } \\
\text { Permissible } \\
\text { Limit for }\end{array}$ \\
Parameters & $\begin{array}{c}\text { Consumption } \\
\text { (WHO, } \\
\text { 2011) }\end{array}$ & 1970 & 1980 & 1990 & 2000 & 2011 \\
\cline { 1 - 5 } $\begin{array}{c}\text { Calcium } \\
\text { (mg/L) } \\
\text { (Range } \\
\text { Variability) }\end{array}$ & 75 & $33-110$ & $30-206$ & $14-140$ & $17-68$ & $8-78$ \\
\cline { 1 - 5 } Mean & 75.42 & 76.74 & 56.45 & 35.81 & 36.33 \\
\hline $\begin{array}{c}\text { Standard } \\
\text { Deviation }\end{array}$ & & 23.92 & 32.33 & 32.6 & 12.94 & 17.63 \\
\hline
\end{tabular}

Source: Central Groundwater Board, India

During 1990, maximum value of calcium concentrated groundwater for study area was decreased and it ranged between 14 to $140 \mathrm{mg} / \mathrm{L}$. Areas consisted in highest calculated range during this period incorporates south western Aur Block of Shahid Bhagat Singh Nagar District, south eastern and north western Phillaur Block of Jalandhar District and western part of Ludhiana II Block of Ludhiana District (figure 1 (c)). For 2000, whole study area was covered under the WHO stated maximum permissible limit of calcium concentration in groundwater (figure $1(\mathrm{~d})$ ). During 2011, it again exceeds its maximum acceptable limit and ranged between 8 to $78 \mathrm{mg} / \mathrm{L}$. This unfit groundwater observed in two patches. One consist a small patch covered 


\section{International Journal of Science and Research (IJSR) \\ ISSN (Online): 2319-7064 \\ Index Copernicus Value (2013): 6.14 | Impact Factor (2015): 6.391}

the north eastern part of Phillaur Block of Jalandhar District. Second patch was found in Ludhiana District containing south western part of machhiwara Block, southern part of Ludhiana II Block and south eastern part of Ludhiana I Block (figure 1 (e)).

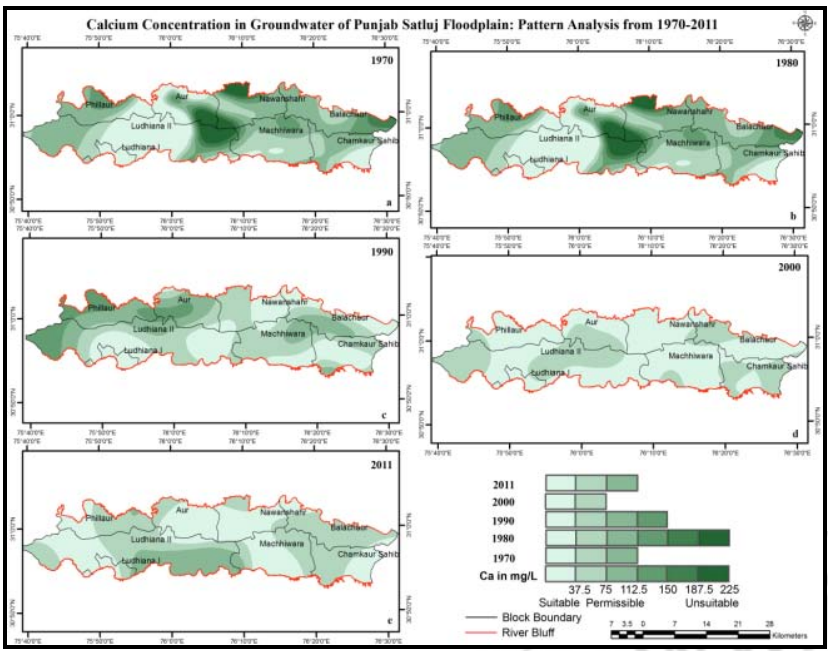

Source: Interpreted from data provided by Central Groundwater Board, India

Figure 1

\section{Conclusion}

Variation has been noticed in the concentration of calcium ion in groundwater of Punjab Satluj floodplain. Maximum concentration beyond acceptable consumption limit has been observed in 1980. High concentration of calcium in water when consumed increased the incidence of cardiovascular diseases in humans and also affects the hardness of water.

\section{References}

[1] World Health Organization, "Guidelines for drinking water quality. International programme of chemical safety, health criteria and other supporting information", pp. 296-459. Geneva, 2006.

[2] Richter, Bernd C. and Kreitler, Charles W., "Geochemical Techniques for Identifying Sources of Groundwater Salinization", pp. 181-201. CRC Press, United States of America, 1993.

[3] Debrewer, Linda M., Ator, Scott W. and Denver, Judith M., "Factors Affecting Spatial and Temporal Variability in Nutrient and Pesticide Concentrations in the Surficial Aquifer on the Delmarva Peninsula", U.S. Geological Survey Scientific Investigations Report 2005-5257: 1-27, 2007.

[4] Nerbrand, Christina; agreus, Lars; Lenner, Ragnhild Arvidsson; Nyberg, Per and Svardsudd, Kurt, "The Influence of Calcium and Magnesium in Drinking Water and Diet on Cardiovascular Risk factors in Individuals Living in Hard and Soft Water Areas with Differences in Cardiovascular Mortality," BioMed Central Public Health, 3, pp. 1-9, 2003.

[5] Skipton, Sharma O. and Dvorak, Bruce I.,"Drinking Water: Hard Water (Calcium and Magnesium)", Neb Guide, University of Nebraska-Lincoln Extension,
Institute of Agriculture and Natural Resources, G 1274, ianrpubs.unl.edu/ live/ g1274/build/ g1274.pdf, 2009.

\section{Author Profile}

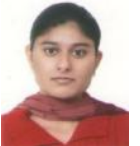

Ms. Harsimrat Kaur Gill is conducting research on „Land use and Land cover Change in Part of Satluj Floodplain, Punjab"e, a theme of regional relevance having global implications from Centre of Advanced Study in Geography, Panjab University, Chandigarh, India. She qualified National Eligibility Test (NET) for lectureship in the subject of Geography conducted by University Grants Commission, New Delhi, India. She is also a recipient of UGC Research Fellowship Award in Science for Meritorious Students for pursuing her Doctorate Degree. In the course of her research she has augmented her research abilities through learning and adopting the state-of-the-art in research techniques within the discipline. She learned varied aspects of Geospatial technology that included Remote Sensing \& GIS-Technology and Applications; Hyperspectral Remote Sensing and Microwave remote Sensing for Natural Resources from National Remote Sensing Centre, Hyderabad and Indian Institute of Remote Sensing, Dehradun, Department of Space, ISRO, Govt. of India. 